\title{
COMPARING ELT POLICIES IN JAPAN AND SOUTH \\ KOREA: DO THEY STILL NEED ENGLISH? \\ (A LITERATURE STUDY)
}

\author{
Abd Rajab \\ Universitas Muhammadiyah Makassar, Makassar, Indonesia \\ rajab@unismuh.ac.id
}

\begin{abstract}
Language policy is one issue that should be highlighted because language policy is one of the most important things to develop in a country. In language, the main goal to be achieved is the successful delivery of our goals and objectives to the listener. Thus, Language policy is concerned with a highly complex issue; therefore, language policy as a separate field of study requires an interdisciplinary approach drawing upon the knowledge and tools of several academic disciplines such as applied linguistics, sociolinguistics, sociology, anthropology, and political theory. This paper aimed to suggest for Indonesia English Education based Japan and South Korea practice in ELT.
\end{abstract}

Keyword: ELT, Language Policy

Published by:

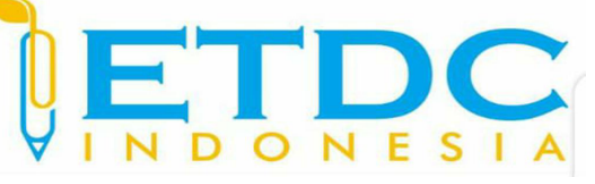

Copyright (C) 2021 The Author (s)

This article is licensed under CC BY 4.0 License

\section{(cc) EY}




\section{COMPARING ELT POLICIES IN JAPAN AND SOUTH KOREA: DO THEY STILL NEED ENGLISH? (A LITERATURE STUDY)}

\section{Introduction}

Language policy is one issue that should be highlighted because language policy is one of the most important things for language development in a country. A language is a communication tool used between one individual and another individual. In language, the main goal to be achieved is the successful delivery of our goals and objectives to the listener. Thus, Language policy is concerned with a highly complex issue; therefore, language policy as a separate field of study requires an inteirdisciplinary approach drawing upon the knowledge and tools of several academic disciplines such as applied linguistics, sociolinguistics, sociology, anthropology, and political theory. Cooper (1989) points out that a lot of progress has been made in the field in the past few decades, but terminological ambiguity is still prevalent.

English has become the language to communicate with people from various countries. This can be seen as a consequence of the globalization era, "Learning an international language is the best choice in a globalized world instead of learning every single language to communicate with foreign people" (Orsel \& Yavuz, 2017). In this case, English is used as Lingua Franca. There are several reasons why English is used widely, "The first one is migration and the second one is colonization (Kachru, 2008).

This paper will describe comparing the English language teaching education policy in Japan and South Korea. Japan needs English, and better English, for reasons that go beyond what is discussed in this paper. One of the aspects that have not been discussed here due to space constraints is the disservice Japan is doing to foreign residents through its lack of English language skills. It was recently revealed that the death rate of foreign residents in Japan is higher than that of the Japanese (The Japan Times, 19 April 2017) (Morita, 2017). and South Korea needs English that "Learning an international language is the best choice in a globalized world instead of learning every single language to communicate with foreign people" (Orsel \& Yavuz, 2017). In this case, English is used as Lingua Franca. There are several reasons why English is used widely, "The first one is migration and the second one is colonization (Kachru, 2008). It is hoped that the present study has given policymakers and teachers in Japan, South Korea and especially for Indonesia. 


\section{Method}

The study has used a literature study. The purpose of a literature study is to analyze a segment of a published body of knowledge critically through summary, classification, and comparison of prior research studies, reviews of literature, and theoretical articles (Embun, 2012). The purpose of a literature study is to analyze critically a segment of a published body of knowledge through summary, classification, and comparison of prior research studies, reviews of literature, and theoretical articles.

\section{Discussion}

\section{Comparing English Language Teaching Education policies in Japan and Korea}

Some researchers have carried out the studies of language policy in Japan and South Korea with varying degrees of success. Generally, these studies are focused on the function of English. Some of these studies are mentioned as follows:

\section{a. English Language Teaching Policy in Japan}

Language education policy in Japan, especially English education, has received much criticism for not having equipped the Japanese with the practical ability to use English. This problem was summarized by Hato (Hosoda et al., 2005) as unrealistic "top-down goal setting" with examination-oriented goals. She explained out that insufficient class time and negative washback effects from impractical goals only exacerbate the Japanese inferiority complex with respect to their English ability. Sasayama (2013) investigates Japanese students' attitude towards English variations of JE and AE to compare. VGT is generally expressed, Japanese respondents return JE and AE very similarly; However, looking at their attitudes more closely, it became clear that they considered JE to be more amenable and AE stronger. Questionnaire results revealed by individuals Want to sound like Americans, in general, but they expect JE, English which may be widely spoken by respondents themselves, to be accepted internationally. People's attitudes toward language or variety are not monolithic and change depending on which aspect of the attitude is investigated. Therefore, it is important to discuss not only people's general language attitudes but their various aspects.

MEXT start to include the introduction of English language teaching from the low level to the top level, where it had previously been started from the first year of junior high school, and the use of a more communicative teaching approach over the previous grammar-oriented, examination-focused one. In preparation for these reforms, MEXT drove experimental initiatives in English and science education from 2002. MEXT had confirmed Super English High School and Super Science High School (English for science course) that programs offer 
promising evidence that innovative approaches to English teaching can be effective in the Japanese EFL environment (Noguchi 2015), (Hatori, 2005). Furthermore, since 2011, MEXT mandated "English activities" to be inserted into the elementary curriculum starting in fifth grade. There are further plans to lower the age of initial English instruction to third grade by 2020, and one can well imagine that elementary school visits by area Assistant Language Teachers (ALTs) are likely to increase in frequency (Boggs, 2018).

Assessment of the Current Policy on English Education

The MEXT plan has problems in terms of resisting linguistic imperialism and reproducing current inequalities. Firstly, it is limited in understanding current situations as they are. It states only the disadvantages that Japanese people experience because of insufficient English competence. Unlike the Council on National Language's report on the Japanese language, movements for respecting a mother tongue and for protecting minority languages in the world are not stated. Also, it still relies on native speakers as models and promotes the JET Program. It does not refer to criticisms that the JET program is costly and has been controversial (Nunan, 2003). On the other hand, teachers who worked with the assistants criticized them for not having an understanding of Japanese culture and for lacking professionalism.

Secondly, the MEXT plan reflects what Pennycook (2001) calls a laissez-faire attitude toward English imperialism. Here, globalization is a given and English is perceived as a necessity for living in the current era. In addition, the primary motivation for supporting English seems to be stated in the first part of the plan, that is, to challenge economic competition. However, if linguicism is analogous with racism and sexism (Phillipson, 1992), then the logic that "You should speak English" becomes synonymous with "You should become Caucasian or male." Under the Constitution's ideal, respect for human rights, Japan should not be a conspirator in imperialism. English imperialism harms language rights (Phillipson, 1992) and a laissez-faire attitude cannot change the status quo (Pennycook, 2001).

\section{b. Language Policy in South Korea}

South Korea is very popular now. South Korea is often called a model country because it has been very successful in terms of both democratization and industrialization in a relatively short period. As Korean society has struggled with globalization over the last decade, it has been necessary for people to be proficient in English. As a result, English language education in Korea has experienced vast changes, aiming at more effective and globalized English language teaching. English is used in advertising and pop culture throughout South Korea, essentially "English remains a foreign language rarely used in Korean's daily lives" (Yoo, 2005). Instead, an interesting social phenomenon has developed as English has become a way 
for South Korean's to measure success. English has become a "symbol of job success, social mobility, and international competitiveness" (Koo, 2007; Yim, 2007).

In Korea, the concept of ,national religion is replaced by ,national language ee since it is a unifying power Koreans are proud of and it is quite homogeneous throughout the country. Lambert expresses this monolingualism as being ,ethnolinguistically homogenous ${ }^{\text {ee }}$ (1999). This situation is changing due to the increasing mobility of Koreans around the world, intermarriages and the migrant workers who are employed in Korea (Chung \& Choi, 2016). English proficiency, in Korea today, is a symbol of prestige, „modernity (Lee, 2006), success and socioeconomic status (Choi, 2007). In South Korea, official English education starts in the third year of primary education. However, it is a known fact that children start learning English earlier than that, either through private pre-schools or publicly subsidized pre-schools that all include English education in their curricula. At the secondary level, English is a compulsory core subject until the first year of senior high school. Although English becomes an optional subject from the second year of senior high school, most students decide to take it due to its perceived importance. Students also receive a lot of English teaching outside of the realm of official public education, e.g., through conversation schools, as reflected in the astrological expenditure on private English education noted above (Chung \& Choi, n.d.).

Till now, we've analyzed Korea's craze for early English Education as a self-portrait of Korean contemporary society and suggested its way to be solved. Due to the change of international environment, the fervor for early English education and the feverish condition of the regular school education, Korea is filled with education fevers, but English education environment condition has proved "ineffective." To solve the problems of English education, we proposed to fundamentally modify the goals of English education in schools by dividing English skills into two: English decoding ability in elementary/secondary schools and communication ability in universities and professional language training institutions. To optimize the use of professionally trained English speakers and to improve world business efficiency in public institutions, we also suggested establishing the system of foreign language expert jobs. To conclude, it's only when all educational requirements (teaching materials, teachers and learning environment, etc.) are well equipped that early may be better than late language start. Some old Korean advocators for early foreign language education give an extreme example of Japanese language education during the Japanese colonial period (19101945), in saying they could speak Japanese well even after several decades, despite their learning Japanese only for six years at elementary school. However, we should remember that Koreans, as subjects of the Japanese emperor, learned all subjects in Japanese at that time. 
Koreans were forced to speak Japanese as an official language in and out of school. On the other hand, it is relatively easy for us to learn Japanese because both Korean/Japanese languages are similar in sound and/or have similar patterns (B. R. Kim, 2015).

Over the past years, there has been an unsurpassed interest in English educational transformation discourse among many stakeholders. This has been a consequence of public outcry over the poor performance of Korean students not only across standardized English tests such as TOEFL and IELTS (ETS, 2010; IELTS, 2011) but also in actual situations of communication (Shin and Shim,2011). Although Korean students invested enormous amounts of time and money learning English, their English proficiency, in general, was lower than the world average (Kang, 2009).

To tackle this problem, the Korean government tried to innovatively revamp the entire secondary English education system over the last decade (H. Lee,2010). Even the past president has emphasized the need for a transformation of English language education in Korea since he was elected in 2008. At the heart of these deliberations is the need to find a lasting solution to English educational challenges. This has led to a proliferation of English educational initiatives across the country.

English language in Korea has a long story, "English language teaching was introduced to Korea in 1883 when the Korean government opened an English language school to train interpreters. For the next twenty years, English, with government backing, started to grow into the status of the most popular foreign language" (Kim-Rivera, 2002). However, the history of English in this country does not stop to this point since "the government involvement in and contributions to the development of the field were interrupted when the country was conquered by Japan at the beginning of the 20th century, and Japanese colonial policies began to impact on the system of English language education"

Revision of the National Curriculum of English in South Korea

To gain a better understanding of the current changes which have been made to the National Curriculum of English, it is essential to look at its history. Since South Korea gained independence from Japan in 1945, the National Curriculum of English has been revised several times and its revision can be roughly described as follows: Initial Curriculum (1946-1954): Structural Syllabus, Grammar-Translation Method, 1st Curriculum (1954-1963): Structural Syllabus, Grammar-Translation Method, 2nd Curriculum (1963-1973): Structural Syllabus, Audiolingual Approach, 3rd Curriculum (1973-1981): Audiolingual Approach, StructuralSituational Approach, 4th Curriculum (1981-1987): Audiolingual Approach, StructuralSituational Approach, 5th Curriculum (1987-1992): Structural-Situational Approach, 6th 
Curriculum (1992-1997): Notional-Functional Approach, 7th Curriculum (1997-2006): LevelDifferentiated Approach, Revised 7th Curriculum (2009-)

There were two sub-curricula of English in South Korea:

1. Common Basic Curriculum of English and Elective Curriculum of English. The Common Basic Curriculum of English was from Elementary school 3rd year (Grade 3) to high school 1st year (Grade 10), and the students were required to take the same English courses, which comprised four skills in one syllabus.

2. The Elective Curriculum of English was from High school 2nd year (Grade 11) to 3rd year (Grade 12), and the students could choose to take more specialized courses such as English conversation, English reading, English writing, etc (Spolsky, 2015).

In 2006 the 7th National Curriculum was partially revised, and this curriculum effectively supported the extension of level-differentiated class plans for English and Mathematics that were announced at the 2004 'Comprehensive Plan of Education for Excellency' by the Ministry of Education (Ministry of Education and Human Resources Development, 2006). The basic principles of English language education at the elementary and secondary levels remained the same as the 7th Curriculum (J-S Kim, 2009; Ministry of Education and Human Resources Development, 2008; Ministry of Education, Science and Technology (MEST), 2008a). The main features of the Revised 7th Curriculum of English can be described as follows:

1. The amount of newly introduced vocabulary for each grade was modified in consideration of the interrelationship between grades and school levels. Moreover, by reducing the differences in terms of grammar and communicative functions between school levels (the elementary school level, the middle school level, and the high school level), the pressure on students, who are going to advance to upper-level schools, is expected to be relieved considerably.

2. The overall difficulty level was lowered by deleting the intensive course achievement standards or by inserting some of them into the basic course achievement standards. Especially, achievement standards related to the productive skills (speaking, writing) were more specifically revised to an achievable level considering the circumstances of English education in Korea.

3. By adjusting and adding 'communicative skills' and the sample sentences and by adopting as many basic words as possible, it is expected to reinforce practical English study by learning more natural and authentic expressions.

4. Cultural contents of textbooks are reinforced by integrating diverse cultures into the 
resource pool. In short, some of the curricula were revised and reinforced by clarifying basic vocabulary principles, separating the objectives among the school levels, and describing the objectives clearly.

In 2009 the revision of the National Curriculum of English was announced and it is called the Revised Curriculum (Korea Institute of Curriculum and Evaluation, 2011b). According to this revised curriculum, new English textbooks were developed in 2012, and the curriculum was incorporated for middle school and high school 1st-year students in 2013.

This curriculum divides the whole period of the curriculum into four school - year groups: Elementary school 3rd-4th-year group (Grades 3-4): 136 hrs (2 hrs/week), Elementary school 5th-6th-year group (Grades 5-6): $204 \mathrm{hrs}$ (3 hrs/week), Middle school 1st-3rd-year group (Grades 7-9): 340 hrs (3-4 hrs/week), High school 1st-3rd-year group (Grades 10-12): 255-425 hrs (3-5 hrs/ week)

Like the 7th Curriculum of English, this curriculum also has two sub-curricula, but the curriculum period is slightly different. The Common Basic Curriculum of English is from Elementary school 3rd year (Grade 3) to Middle school 3rd year (Grade 9). The Elective Curriculum of English is from high school 1st year (Grade 10) to 3rd year (Grade 12). Consequently, all the high school courses are elective.

Two tendencies in The Use of the English language in South Korea

1. English for Korean purposes. Koreanized English words

English vocabulary in the Korean language comprises a wordsctock that consists, on the one hand, of real English words derived either from US and British English or via Japanese and, on the other hand, of the so-called pseudoEnglish words that have no equivalents in US or British English. Speaking about the first group, the Korean language imports many English (mostly US English) words which reflect various aspects of Western culture.

2. English proficiency and English communicative skills of Koreans

The active use of English material by Koreans that we discussed above does not imply mass Korean-English bilingualism as a societal phenomenon. Regarding mass bilingualism (societal), when two languages are used in the complementary spheres, we argue that it is more reasonable to adopt the upper point of the bilingual continuum which corresponds to high or close to the high level of language proficiency. However, it does not mean that only people who are fluent in English are enough to constitute mass bilingualism if a language, they are proficient at, is not use $d$ as an independent and separate linguistic code in the complimentary spheres together with a native language. Thus speaking of mass bilingualism as a societal phenomenon we should consider both the functional and linguistic aspects. Though there 
is another approach to mass bilingualism. For example, in the similar but not identical situation in Russia, (Fayzrakhmanova, 2016) accepts mass Russian-English bilingualism in its passive and minimal form. In South Korea functions of the English language as a separate linguistic code are rather limited. It is used mostly in intercultural communication. English proficiency in Korea remains at a moderate level and many Koreans lack English communicative skills.

Conclusion, Many Koreans lack English communicative skills that can be explained by a long period of grammar-translation method in English education. Recently they started to pay more attention to communicative methods, for example, the implementation of CLT (communicative language teaching) since 1992. Though in general, a formal approach dominates English in education in Korea, it fits well with the conditions of Korean education, where students have a passive role that cannot facilitate the development of communicative skills. Thus the English language situation in Korea is quite paradoxical. On the one hand, the English language is very popular in Korea and English linguistic material is used in various spheres of Korean life from business to mass- media and tourism. On the other hand, English proficiency remains at a moderate level that can be explained by a range of sociocultural and linguacultural factors(Fayzrakhmanova, 2016).

Table 1. Comparing English Language Teaching Policy in Japan and South Korea

\begin{tabular}{|c|c|c|}
\hline Policies & Japan & South Korea \\
\hline $\begin{array}{l}\text { Access (what, to } \\
\text { whom, and } \\
\text { when) }\end{array}$ & $\begin{array}{l}\text { School and local governmental } \\
\text { choice as part of International } \\
\text { understanding since } 2001 \\
\text { To apply for 5th \& } 6 \text { th for } 40 \\
\text { min. per week from } 2011 \\
\text { (Spolsky, 2015) }\end{array}$ & $\begin{array}{l}\text { Compulsive \& academic subject/ } \\
\text { nationwide since } 1997 / 40 \text { min. per } \\
\text { week for 3rd and 4th grades; } 80 \\
\text { min. for 5th and 6th grades (since } \\
\text { 2001)/ The government plans to } \\
\text { increase the number of instructional } \\
\text { hours (Spolsky, 2015) }\end{array}$ \\
\hline Personal (Teacher) & $\begin{array}{l}\text { Focus on Primarily homeroom } \\
\text { teachers, NEs (Butler, 2018) }\end{array}$ & $\begin{array}{l}\text { Focus on Local teachers of English, } \\
\text { homeroom teachers, NEs (Native } \\
\text { English Speakers) } \\
\text { The government plans to hire } \\
\text { instructors who specialize in } \\
\text { teaching oral English (Butler, 2018) }\end{array}$ \\
\hline $\begin{array}{l}\text { English Proficiency } \\
\text { Globalization } \\
\text { Curriculum } \\
\text { (Objectives) }\end{array}$ & $\begin{array}{l}\text { TOEFL and IELTS } \\
\text { the challenges of globalization } \\
\text { understanding different } \\
\text { cultures/ To develop a sense of } \\
\text { self and of what it means to be } \\
\text { Japanese/ To develop basic } \\
\text { foreign language skills and } \\
\text { other communicative skills }\end{array}$ & $\begin{array}{l}\text { TOEFL and IELTS } \\
\text { the challenges of globalization } \\
\text { Developing basic communication } \\
\text { skills/ To develop students' interests } \\
\text { and positive attitudes towards } \\
\text { English learning/ To learn different } \\
\text { cultures and customs through } \\
\text { English }\end{array}$ \\
\hline Methodology & Various types of materials have & One textbook based on National \\
\hline
\end{tabular}




\begin{tabular}{|c|c|c|}
\hline and materials & $\begin{array}{l}\text { been used depending on } \\
\text { schools/ From 2011, a textbook } \\
\text { for each grade produced by the } \\
\text { JMOE (Ministry of Education, } \\
\text { Culture, Sports, and } \\
\text { Technology in Japan) will be } \\
\text { introduced }\end{array}$ & $\begin{array}{l}\text { Curriculum for each grade } \\
\text { approved by the government/ } \\
\text { Primarily oral language / written } \\
\text { language is introduced from the } 2^{\text {nd }} \\
\text { semester of the } 3^{\text {rd }} \text { grade/ Teaching } \\
\text { English through the medium of } \\
\text { English (TETE) is strongly } \\
\text { recommended }\end{array}$ \\
\hline Community & $\begin{array}{l}\text { Various after-school programs/ } \\
\text { TV and radio programs/ } \\
\text { Private English language } \\
\text { schools }\end{array}$ & $\begin{array}{l}\text { Various after-school Evaluation } \\
\text { (assessment and evaluation) } \\
\text { programs/ English villages/ Local } \\
\text { English learning centres/ English } \\
\text { TV channels/ Private English } \\
\text { language schools }\end{array}$ \\
\hline $\begin{array}{l}\text { Evaluation } \\
\text { (assessment and } \\
\text { evaluation) }\end{array}$ & $\begin{array}{l}\text { No assessment is required } \\
\text { since English has not been } \\
\text { taught as an academic subject }\end{array}$ & $\begin{array}{l}\text { Teacher-based assessments (e.g., } \\
\text { portfolios, interviews, checklists) } \\
\text { are recommended/Verbal } \\
\text { descriptions by teachers but no } \\
\text { numerical grading systems/ } \\
\text { National Academic Achievement } \\
\text { Test for select schools/ KICE (the } \\
\text { Korea Institute of Curriculum and } \\
\text { Evaluation) is developing an } \\
\text { English test. }\end{array}$ \\
\hline
\end{tabular}

Note: JMOE: Ministry of Education, Culture, Sports, and Technology in Japan KMOE: Ministry of Education and Human Resources Development in Korea (Butler, 2018)

\section{Conclusions}

To sum up in Comparing English Language Education Policies in Japan and South Korea above. This paper suggests for Indonesia English Education. Japan and South Korea are two countries that have a strong country. So, they don't need an English to develop their country because their country is already developed and strong, but they still need to learn English for the benefit of their country. English education policy has been started in elementary school. This indicates how important English is mastered as an international communication way. Based on the two countries, it might be as reflection for Indonesia. Therefore, Indonesia, which is classified as a developing country that is certainly in need of mastering English as an international language for the progress of this nation in globalization. Indonesia needs to make an English education policy to mastery English from chilhood so that English can be a power to develop the Indonesian at an international level. Indonesia needs to use how English is used as a facilitation to introduce culture, natural resources and etc to globalization where we know English is one of the international languages. thus, Indonesia needs to master English as early as possible to reach that goal. The students should study English from elementary school but the students should be study English based on their needs. Thus, language policy needs to make 
policy especially in English Policy that the students can study English starting from preschool until secondary school. The English subject is not compulsory but as optional based on the students' needs. Supporting, (McKay, 2004) found that students believed their elementary school English had a positive effect on their English learning at middle school in the domains of reading, speaking, and listening. Similar results were reported in (J. H. Kim et al., 2011). But we need to see first in Indonesian context before taking the policy. we need to see SocioCultural, Political, and Geographical before give the recommendation. In Indonesian context, teaching language is very unique and difficult not only in teaching English but also Bahasa Indonesia that Indonesian people know that Bahasa Indonesia is Bahasa Negara Indonesia. This has been to a great extent attributable to the multicultural and multilingual nature of Indonesian society, in which one can easily identify differences - in language, ethnicity, and culture to mention a few (Madya, 2008). According to Ethnologue 2005 (Rachman in (Madya, 2008)), Indonesia has 745 local languages, of which 271 are in West Papua, and dialects with their own characteristics and about 350 ethnic groups and tribes, with their own customs, types of villages, social structure, beliefs and religions. Throughout South-East Asia, this country probably has the greatest diversity of culture, caused by differing histories of the people's contact with and responses to the outside world (Geertz in (Madya, 2008)). With all of these differences, however, the people are being united by being Indonesian recognizing Indonesia as the only home water-land and Bangsa Indonesia the only nation, and esteeming highly Bahasa Indonesia as the only uniting language, as stated in the 1928 Youth Oath long before this country got its independence in 1945. All of this is clearly expressed in the motto Bhineka Tunggal Ika or Diversity in Unity.

To support the recommendation, the policy maker need to know the importance of ideology in L2 education. Ideological analysis in L2 education reveals that social and political agendas call ideologies into service in the process of allocating resources and benefits to different social groups. Standard language ideology, the ideology of monolingual (English) classrooms, the ideology of variation, and implicit ideologies in teacher education, SLA, research methods, and other aspects of L2 education have direct consequences for social positions of learners, teachers, and others; and it is in such social positions that individuals gain (or are denied) access to economic resources and political power.

\section{REFERENCES}

Adz Dzaky, S. Z., Badarudin, B., \& Muslim, A. H. (2020). Analisis Kompetensi Guru Dalam 
Penguasaan Teknologi Informasi Dan Komunikasi Pada Pembelajaran Di Sekolah Dasar Negeri 2 Purbalingga Lor. School Education Journal Pgsd Fip Unimed, 10(1), 27. https://doi.org/10.24114/sejpgsd.v10i1.18036

Boggs, J. A. (2018). Teaching English in East Asia. In System (Vol. 72).

Butler, Y. (2018). Issues in the Assessment and Evaluation of English Language Education at the Elementary School Level: Implications for Policies in South Korea, Taiwan, Issues in the Assessment and Evaluation of English Language Education at the Elementary School Level. December.

Chung, J., \& Choi, T. (n.d.). English Education Policies in South Korea : Planned and Enacted. 281-299. https://doi.org/10.1007/978-3-319-22464-0

Cooper, A. C. (1989). Research findings in strategic management with implications for R\&amp;D management. R\&D Management, 19(2), 115-125. https://doi.org/10.1111/j.1467-9310.1989.tb00632.x

Embun, B. (2012, April 17). Banjir Embun. Retrieved from Penelitian Kepustakaan: http://banjirembun.blogspot.co.id/2012/04/penelitian-kepustakaan.html

Fayzrakhmanova, Y. (2016). English in South Korea: Two Sides of the Same Coin. Procedia Social and Behavioral Sciences, 236(December 2015), 168-173. https://doi.org/10.1016/j.sbspro.2016.12.059

Hatori, R. (2005). A policy on language education in Japan: Beyond nationalism and linguicism. Second Language Studies, 23(2), 45-69. http://hawaii.edu/sls/uhwpesl/23(2)/6 Hatori $\underline{\text { Reiko.pdf }}$

Hinkel, E. (n.d.). Handbook of Research in Second Language Teaching and Learning Volume II.

Hosoda, Y., Gebhard, J. G., Westrick, P. A., Brauer, H. E., Simms, D. L., Cornwell, S., Brown, J. D., Hinkel, E., \& Murphey, T. (2005). 全国語学教育学会 jalt journal Japan Association for Language Teaching. 27(1). http://www.jalt-publications.org/ji

Kachru, Y. (2008). Language variation and corpus linguistics. World Englishes. https://doi.org/10.1111/j.1467-971X.2008.00532.X

Kim-Rivera, E. G. (2002). English Language Education in Korea Under Japanese Colonial Rule. Language Policy. https://doi.org/10.1023/A:1021144914940

Kim, B. R. (2015). The English Fever in South Korea: Focusing on the Problem of Early English Education. Journal of Education \& Social Policy, 2(2), 117-124. www.jespnet.com.

Kim, J. H., Lee, S. R., Li, L. H., Park, H. J., Park, J. H., Lee, K. Y., Kim, M. K., Shin, B. A., \& Choi, S. Y. (2011). High cleavage efficiency of a $2 \mathrm{~A}$ peptide derived from porcine teschovirus-1 in human cell lines, zebrafish and mice. PLoS ONE. https://doi.org/10.1371/journal.pone.0018556 
Madya, S. (2008). Curriculum Innovations in Indonesia. ELT Curriculum Innovation and Implementation in Asia, 2, 1-38.

McKay, S. L. (2004). Teaching english as an international language: The role of culture in Asian contexts. Journal of Asia TEFL.

Morita, L. (2017). Why Japan needs English. Cogent Social Sciences, 26, 1-11. https://doi.org/10.1080/23311886.2017.1399783

Orsel, C., \& Yavuz, F. (2017). A Comparative study on English language teaching to young learners around the world. Contemporary Educational Researches Journal. https://doi.org/10.18844/cerj.v7i3.2656

Sasayama, S. (2013). Journal of Multilingual and Japanese college students 'attitudes towards Japan English and American English. December 2014, 37-41. https://doi.org/10.1080/01434632.2013.767341

Spolsky, B. (2015). Secondary School English Education in Asia. In Secondary School English Education in Asia. https://doi.org/10.4324/9781315760636 